\title{
Powtoon Animation Video: A Learning Media for the Sixth Graders
}

\author{
G. A. P. Suprianti
}

Universitas Pendidikan Ganesha, Indonesia

Correspondence: G.A.P. Suprianti, Universitas Pendidikan Ganesha; Indonesia. e-mail: gap.suprianti@undiksha.ac.id

Submitted: September 01, 2020

DOI: $10.29408 /$ veles.v4i2.2536
Revised: September 22, $2020 \quad$ Accepted: September 30, 2020

URL: http://dx.doi.org/10.29408/veles. v4i2.2536

\begin{abstract}
In this global era, everything changes into technology-based likewise teaching method. In teaching, technology can be used as teaching variation and this study was aimed to develop technology-based English language learning media for sixth grade elementary students by using Powtoon animation video. This study's objectives was for developing the prototype product. This study used Design and Development (D\&D) method by three steps based on ADDIE model. The stages are analysis, design, develop. Since the steps used were only three, then the product was only in the form of prototype product. In order to develop the prototype product, need analysis, designing the product based on the analysis, and then development were done. The product was quantitatively analyzed by using expert judgment. The result of the experts judgment showed that the prototype product was categorized as an excellent media after some revisions and suggestions from material and IT expert.
\end{abstract}

Keywords: English for young learners, learning media, Powtoon.

\section{Introduction}

English is international language. It is an international language because of the number of its user increase significantly (Basthomi, 2007). English has a big role in the global communication and many countries have used it. English is usually used in aspect of life such as communication, education, business, etc. English is needed not only by adult but also by children or teenager. People from every age need to learn English in order to be ready to face the globalization. Then, in learning English there are four skills that should be mastered. They are Listening, Speaking. Reading, and Writing. Each of them has an important role. Then, one tool that can be used to teaching these four skills as integrated learning for young and adult learner is by using media.

Media plays a significant role in the language learning process. Learning media are divided into three types, that is, audio, visual and audio-visual media. Briggs, Gustafson, \& Tillman (1991) argues that all the physical tools, both printed and audiovisual with all the equipment, 
which can present the messages and can stimulate students to learn are considered as media. The existence of the media itself is to help teacher whenever the explanation cannot be understood. In other words, media helps students master the material. So, teacher needs appropriate media in order to make students understand the explanation. Then, the media is very important in the learning process. On the other hand, learning media can be very crucial to teach young learner. It is because to teach young learner is more difficult than teach adult learner. So, learning media can be very helpful to teach young learner.

Related to the young learner, media that usually used to teach is not only in the form of traditional media but also in the form of technology. The example of traditional medias are typical toys and materials like dolls, puzzles, and flash card. Then, in the form of technology is like video, song, etc. According to Lee (2015), children or young learner frequently use interactive technology like mp3 player, television, video as the dominant activities in their playing time. Especially the young learners who were born from 1990 to 2010, they are called as z-generation because they are digital natives Seemiller \& Grace (2017). Digital media is like an addiction to them. It changes their daily life activity, communication, even the methods of learning. So, digital media can be very helpful to help young learner learn from the reflection of how z-generation play, learn, and communicate.

Furthermore, the most common ICT (technology) based media used by teacher is PowerPoint. But, there is an ICT-based learning media with an interesting audio visual, animation, easy to operate, easy to be made, so it can be adjusted with learning material that want to be delivered. It is called by Powtoon (Semaan \& Ismail, 2018). Powtoon can be used in the learning process like watching a YouTube video. Teacher can also share it to the students by using YouTube, then students can watch the video outside the school by using smartphones or laptop.

Several studies have proven the implementation of Powton in teaching and learning process. The first study was conducted by Pais, Nogués, \& Muñoz (2017). The study showed positive results on the use of PowToon, such as on the motivational aspect, contribution on learning new contents and developing ICT related abilities. Similar study focused on Powtoon was also conducted by Puspitarini, Akhyar, \& Djono (2016). Research and development (R \& D) developed using the ASSURE model was implemented. The aim of the research was to: 1) develop video learning media on IPS subjects for five elementary school classes, and 2) determine the feasibility of learning video media based on experts and students. The next study about Powtoon was also conducted by Suprianti, Mahayanti, \& Suarjaya (2020). It resulted PowToon animation based-video can be used to teach English for third-grade students of elementary school. From the students' questionnaire, it found that the animation video could attract the students' attention and it also motivated the students during the teaching and learning process.

Then, based on the preliminary research and interview conducted to the students and teacher at SDN 3 Banjar Jawa, The teachers said that they have facilities like LCD, software, $\mathrm{CD}$, and they will be very beneficial if they are used in the learning process. For a while, ICT- 
based learning process only happen if there is a special moment. On the other hand, the teachers cannot make their own ICT-based learning media because they are unable or unskilled. But, some teachers already have their own learning media that they have downloaded from YouTube. Then, based on the questionnaire given to 30 students of six grade at SDN 3 Banjar Jawa, the result of this observation shows $19.3 \%$ students always use smartphones or laptop outside the school, $48.4 \%$ students often use smartphones or laptop outside the school, and $32.3 \%$ students rarely use smartphones or laptop outside the school. So, most of the students use smartphone or laptop outside the school. Most of them use smartphones or laptop to watch YouTube, online reading, and play game. Students also want to learn by using smartphones or laptop. It showed by $96.8 \%$ students choose to learn by using smartphones or laptop. Then, $87.10 \%$ students said that the teacher never use any medias like hand phone or laptop in teaching. Meanwhile, 58.10\% students said that the teacher teach in various conventional way like discussion, singing, and quiz, and 3.2\% students choose not to learn by using smartphones or laptop. They also will be interested to learn English if this research develops a technology based media. It showed by $100 \%$ students choose will be interested to learn English if the researcher makes a technology based media.

According to Suprianti, Mahayanti, \& Kusuma (2018), teacher mostly teach vocabulary by using conventional way such as giving vocabulary list to the students and asks them to memorize it, and using handbook, and flashcards. Then, since the teacher only taught in conventional ways, the teacher also needs to encourage the students to use technology in learning. Then based on the preliminary research, it is needed to develop a technology based learning media to teach young learners about English. Powtoon video can be an appropriate learning media because it is easy to use, it can help students make their own learning experiences by using interesting audio and visual.

\section{Method}

This study is a Design and Development Research (DnD). DnD is a method that focuses on designing, creating and evaluating instructional and non-instructional products and tools and new or enhanced models (Richey \& Klein, 2016). The present study designed, created and evaluated instructional prototype in the form of Powtoon animation video for the sixth graders. In addition, ADDIE (Analyze, Design, Development, Implementation, and Evaluation) model from Romiszowski (1984) was employed in the study.

\subsection{Data Collection}

In order to collect the data, interviewing the teacher, observing the teaching and learning process, distributing questionnaire to the students were done. There were two types of questionnaires used in the study, that is, questionnaire to be distributed in the beginning of the study and questionnaire to be distributed after the product were tried out. The first questionnaire was used for the purpose of knowing the problem and needs of the product development while the second one was used for the purpose of knowing the response of the students about the product. Each of them consisted of 15 items and 8 items. Those questionnaires were adopted from Hari 
(2019). In developing the prototype, there were 2 material experts and 1 IT expert to judge whether the product was ready to be used. The expert judgment was done twice, before the product revision, and after the revision of the product. All of the experts were given rubric and scoring rubric in rating the product. The rubric for material experts was developed based on two major criteria, namely Material Suitability (7 descriptors) and Physical Design Suitability (11 descriptors). The rubric for IT experts was also developed based on two major criteria, that is, Face to Face ( 5 descriptors) and Multimedia (5 descriptors). For the rubric for material experts, maximum score was 5 and minimum score was 1 . Score 5 represented highly appropriate, and 1 represented highly inappropriate. Then, the maximum score became 75 and the minimum score became 15. The same scale was also employed for the rubric given to IT expert. Therefore, for 10 items in total, the maximum score was 50 and minimum score was 10 . Table 1 shows how maximum and minimum scores were quantified into the categories of the Powtoon.

Table 1. The categories in rating the animation video based on Powtoon

\begin{tabular}{ll}
\hline Score & Criteria \\
\hline $\mathrm{X} \geq \mathrm{Mi}+1.5 \mathrm{Sdi}$ & Excellent \\
$\mathrm{Mi}+0.5 \mathrm{Sdi} \leq \mathrm{X}<\mathrm{Mi}+1.5 \mathrm{Sdi}$ & Good \\
$\mathrm{Mi}-0.5 \mathrm{Sdi} \leq \mathrm{X}<\mathrm{Mi}+0.5 \mathrm{Sdi}$ & Average \\
$\mathrm{Mi}-1.5 \mathrm{Sdi} \leq \mathrm{X}<\mathrm{Mi}-0.5 \mathrm{Sdi}$ & Below Average \\
$\mathrm{X}<\mathrm{Mi}-1.5 \mathrm{Sdi}$ & Poor \\
\hline
\end{tabular}

(Nurkancana \& Sunartana, 1992)

Notes:

$\mathrm{Mi}=1 / 2($ Score Max + Score Min $)$

Sdi $\quad=1 / 3(\mathrm{Mi})$

$\mathrm{Mi} \quad=$ the Ideal Mean

Sdi $\quad=$ the Standard of Deviation

$\mathrm{X} \quad=$ The Score of the teacher

Table 2 and Table 3 are resulted from the quantification of rubric for material experts and IT expert. These following categories were used by each expert in rating the Powtoon.

Table 2. The categories used by material experts

\begin{tabular}{ll}
\hline Score & Criteria \\
\hline$X \geq 52.5$ & Excellent \\
$47.5 \leq X<52.5$ & Good \\
$42.5 \leq X<47.5$ & Average \\
$37.5 \leq X<42.5$ & Below Average \\
$X<37.5$ & Poor \\
\hline
\end{tabular}

Table 2 . The categories used by IT expert

\begin{tabular}{ll}
\hline Score & Criteria \\
\hline$X \geq 45$ & Excellent
\end{tabular}




\begin{tabular}{ll}
$35 \leq X<45$ & Good \\
$25 \leq X<35$ & Average \\
$15 \leq X<25$ & Below Average \\
$X<15$ & Poor \\
\hline
\end{tabular}

\subsection{Data Analysis}

In analyzing the data, both quantitative and qualitative techniques were applied by the researcher. The qualitative analysis was for analyzing the result of the questionnaire, observation, and interview. Observation was done at the implementation of Powtoon to get information about what already happened during the teaching and learning process. Along the observation phase, an observation checklist consisting of 15 items was used as a guidance. This checklist was adapted from Harmer (2015). The interview was done twice to the teacher. The first interview consisting of 3 questions was done for the purpose of obtaining information about the school's facilities, and the scope of the material that needs to be developed into a video. Then, the second interview consisting of 10 questions was done after the product implementation in the class for the purpose of gaining information whether the product was appropriate for the teacher's needs. The items in the first interview were developed based on theory from Çakici (2016) and Loukotková (2011). Meanwhile, a theory from Semaan \& Ismail (2018) was used in developing the second interview. The categories mentioned in the interview were (1) Powtoon will support the teacher in the teaching and learning process, (2) Powtoon make it easier to deliver a concept/material, (3) Powtoon can easily attract the students' attention, and (5) PowToon enables the teacher to design a various learning activity. In addition, the Powtoon video's content was analyzed quantitatively using a formula stated in Table 1 (Nurkancana \& Sunartana, 1992).

\section{Results and Discussion}

The product produced by this study was in the form of learning media using Powtoon for transportation topic in sixth grade elementary school. The research model of this study was ADDIE that was done until development step as this article to answer the research question about the Powtoon animation based-video development as an English language learning media for sixth grade. Moreover, the steps of the development are explained in this part. The first was analyzing. In analyzing, all problem and issues in the students' environment were analyzed or called by need analysis. Then, the researcher has conducted the preliminary questionnaire given to the students and interviewed the English teachers at SDN 3 Banjar Jawa to get the need analysis. As the result of the questionnaire and interview, there were five conclusions. First, based on the questionnaire most of the students have smartphones. Second, the students can operate smartphones and laptop. Third, the English teacher at SDN 3 Banjar Jawa did not have any experiences and skill in making their own ICT-based learning media maximally. Fourth, they cannot use ICT facilities and infrastructures maximally. Fifth, most of the teachers did not have ICT-based English language learning media. Then, this research should be conducted. 
The second was designing the product. This step was conducted after the analysis step. The design of the learning media was developed based on the syllabus analysis. Then, the focus on designing the product is the content, the questions, the picture and the setting. The result of this step was the blueprint or the draft of the media that consists of pictures and animation used.

The third was developing the product. The result of this step is explained as follows: (1) The material and IT expert judgment before and after the revision, (2) The final prototype product of Powtoon animation based- video for transportation topic.

From the first material expert gave total score 75 which meant the media was an excellent media. Then after the revision, the first material expert gave 75 which meant the media was an excellent media. Next, the second material expert gave 73 before the product revision which meant that the product was an excellent product. After the product revision, the second material expert gave 74 which meant the product was an excellent product. Last but not least, the IT expert gave 94 which meant the product was an excellent media then it turned into 97 or excellent media after the revision. Then, the example of final prototype for transportation topic can be as follows.

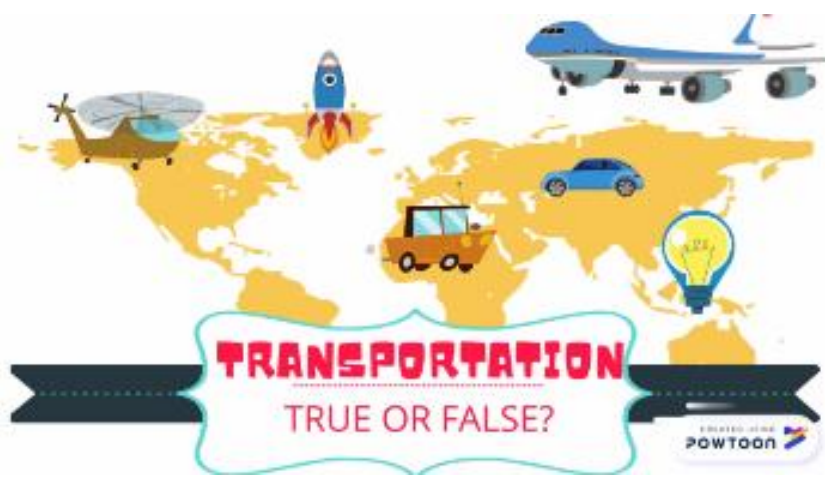

Figure 1. The Prototype for Transportation Topic

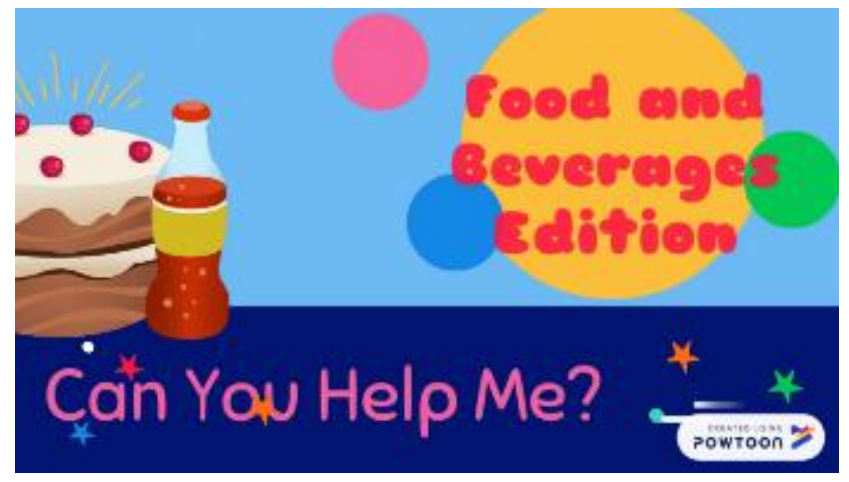

Figure 2. The Prototype for Food and Beverages Topic 


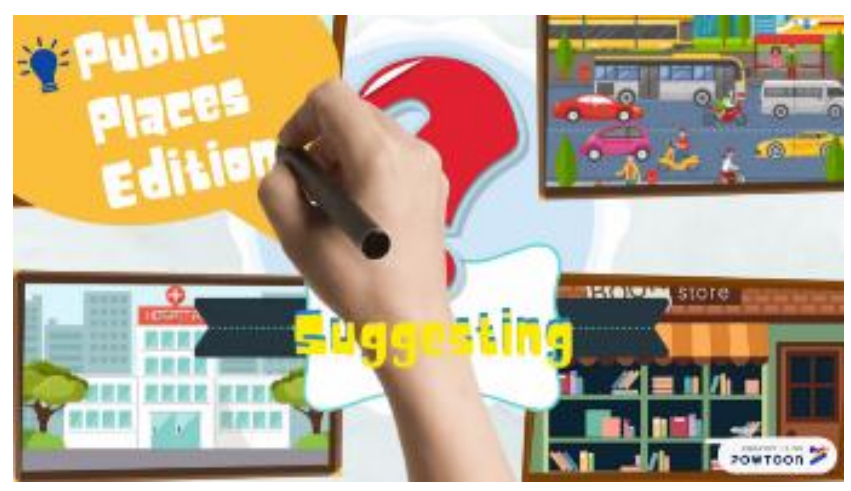

Figure 3. The Prototype for Public Places Topic

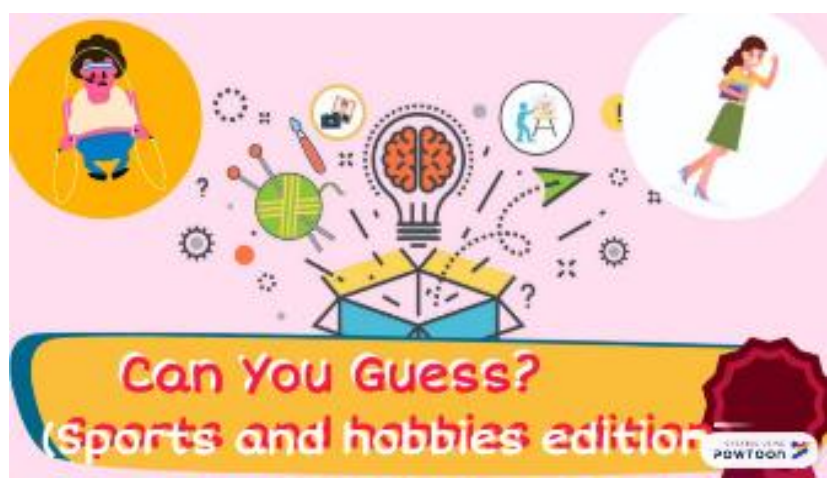

Figure 4. The Prototype for Sports and Hobbies Topic

\section{Discussion}

In this discussion, the finding above is discussed. As the objective of this study was for developing and knowing the quality of an English learning media by using Powtoon application for sixth grade students in SD Negeri 3 Banjar Jawa, then the developed product was about Powtoon animation-based video. In developing the product, the method used was Design and Development proposed by Richey \& Klein (2016) with ADDIE development model. There are five stages used. They are analyze, design, develop, implement, and evaluation. The development of the product based on the need analysis from students' questionnaire, teacher's interview, and syllabus analysis. Then, the result of analysis was designed into product's blueprint and developed into a Powtoon animation-based video with experts' validation. Then in seeking the quality of the product, the product was implemented in the real teaching and learning activity in SD Negeri 3 Banjar Jawa. Moreover in order to find the quality of the product, the students and teacher's response was used. In order to gather the information, students' questionnaire, teacher's checklist and questionnaire were used. 
In order to find the need analysis the researcher conducted preliminary observation on January 10th, 2019. The need analysis consisted by students' questionnaire, and teacher's interview. Based on the preliminary questionnaire given to the students in order to know the need analysis, it showed that the students were very familiar into technology as they are generation $\mathrm{Z}$ who everyday life are involved by technology. They used their smartphone for playing game, reading online story, watching YouTube video and social media. This became a good opportunity for the researcher since the quiz or game combined game, reading, and video as one. Game can be a good learning media since same words or sentences were repeated again and again. As Turgut \& Irgin (2009) state that the students or viewer can saw similar or same commands and directions in English every time and it gave the chance to practice unknown words delivered from different tasks ans stages during the game. Then according to Gass and Selinker, as cited in Turgut \& Irgin (2009), language learners were allowed to be exposed to the target language and were given a chance to make language acquisition by the games' natural repetition. Moreover, this supported the game as a natural language acquisition for the language learner. Despite the finding that students were able to operate PC or smartphones very well, and the school had their own technology support like PC, Wi-Fi, and LCD projector, the problem found was about the teacher who never or rarely used technology and unskilled to made their own teaching media. As argued by Gilakjani (2013), there are five reasons that encourage a teacher to use technology to teach, such as the capability to use a technology, the teaching experience, the inadequate technology device support, the teacher's pedagogical practices, and professional development in technology integration. Then based on the interview done to the teacher, the school had provided adequate technology device support, the teacher were experienced enough to teach, and their pedagogical practice were possible to include technology within the activity but they were not capable to use the technology, and had inadequate professional development in technology device support.

Then, based on the result of the observation, it also found that the students need a new variation in learning English in order to not make the class boring. The preliminary observation showed that the teacher taught in monotonous way such as just answering the exercise book and it may made the students boring because as Porvaldsdóttir (2008) state that short attention span is one of the five important characteristics of young learners aside that they are self-centeredness, learning through senses, possessing natural curiosity, and learning through playing. Despite of the finding that the students were very familiar to the technology, the use of video presentation tool helps the students to be more motivated, comfortable in the teaching learning activity and readier to receive concept (Semaan \& Ismail, 2018). Then, this Powtoon animation based-video is suitable as an English learning media because the students can learn English through watching a presentation video.

After the preliminary observation, the researcher analyzed the sixth grade syllabus, and the teacher's interview result in order to find the topics that should be developed into prototype product and the scope of the topics or material. Then, there were four topics needed to be developed. They were food and beverages, public places, transportation, and sport and hobby. 
Then, the researcher made a blueprint as the guidance of the product development. The blueprint was made from the picture and material collected after the topics were gained. The picture was selectively chosen in order to make the picture represent the material well. The visual chosen was interesting and colorful in order to attract the students' attention. As supported by Sousa, as cited in Semaan \& Ismail (2018), visual helps the students to increase the possibility of the sense and meaning will be emerged and the students will be able to receive the information accurately by attaching both auditory and visual to the information. In addition, since Powtoon animationbased video contains interesting audio and visual, it will make the students understand the material better (Turgut \& Irgin, 2009).

After the blueprint of the product was designed, the product was developed based on the guidance. The researcher conducted consultation with the material and IT expert in developing the prototype product. After the product finished, the first expert judgment before product revision was done. There were some revisions and suggestion during the first expert judgment in order to make a good learning media that make students excited to learn English and play at the same time. Then, the result of expert judgment was formulated using Nurkancana \& Sunartana (1992) formula. The expert judgment was done twice, before revision and after revision. Before the revision of the product, the first material expert gave 75 points. Then, the second material expert gave 73 point and the IT expert gave 94 points. The material judgment by the first, second, and the IT expert categorized the prototype product as an excellent media. But, this media still far from perfect and there were some mistakes on grammar, word's spelling, and the color of the font that needed to be revised in order to make better media. Those mistakes furthermore will be revised. After the revision was done, the expert judgment on material and IT is done. After the revision, the first material expert gave 75 points and the second material expert gave 74 points. Meanwhile, the IT expert gave 97 points. As the result, the material judgment by the first and second expert, and also IT expert categorized the media as an excellent media. It was because the revision was done in accordance with the experts' suggestions.

In doing this study, there were some implications faced by the researcher. Firstly, since this study had short period to be done with the result that this study only implemented in one school. Whereas, it can be implemented in many schools to know the wider impact of the prototype product if it was done in long period of time. Secondly, the limitation of the prototype product's time since it was not in a premium version with the result that, the video only contained few vocabularies because of the time limitation. Besides by using the premium version, the prototype product will not have any limitation and make the learning process is not limited. Thirdly, the evaluation was only in the form of perceptional answer. Then, it is good if the Powtoon application can be used in other field than English. It may be used for science, history, or even math.

In addition, the impact of this study for the teacher and students was the teacher can gain new knowledge about Powtoon application. The teacher also got some new learning media that can be used in the classroom. Then, the students can gain new vocabularies from the Powtoon video they have watched and by game they have played. The learning activity will not become so 
monotonous, with the result that the students will be more focused on the learning process. Afterwards, they can also learn outside the school through internet since internet is part of their daily life.

\section{Conclusions}

This study was a Design and Development that was aimed at developing ICT-based English Learning media by using Powtoon animation-based video as an integrated learning for sixth grade students at SD Negeri 3 Banjar Jawa, Singaraja. Based on the result of the analysis and problem's statement, the researcher concludes as there were four topics developed into Powtoon animation-based video in this study. They were food and beverages, public places, transportation, and sport and hobby. Each topic contains different type of questions such as multiple choices, short essays, true of false, and guessing. Afterwards, the prototype product was designed based on the syllabus analysis, and the experts' judgment rubrics and suggestions. In conducting the expert judgment rubric, the allover result from the material experts and IT expert was categorized the media as excellent. But, there were some revision still needed in order to make the quality of the product better such as grammar mistake and color selection. Then, after the revision the material and IT expert categorized the media as excellent.

\section{References}

Basthomi, Y. (2007). Reviewing the discourse on (potential) "enemies of standard English." TEFLIN Journal, 18(2), 159-168. https://doi.org/10.15639/teflinjournal.v18i2/159-168

Briggs, L. J., Gustafson, K. L., \& Tillman, M. (1991). Instructional design: Principles and applications. Educational Technology Publications.

Çakici, D. (2016). The use of ICT in teaching English as a foreign language. Participatory Educational Research (PER), Special Is(IV), 73-77. https://doi.org/10.2307/3585495

Gilakjani, A. P. (2013). Factors contributing to teachers' use of computer technology in the classroom. Universal Journal of Educational Research, 1(3), 262-267. https://doi.org/10.13189/ujer.2013.010317

Hari, K. W. (2019). Developing Powtoon animation based-video as media to teach English for second grade students of elementary school.

Harmer, J. (2015). The practice of English language teaching. USA: Pearson Education ESL.

Lee, L. (2015). Digital media and young children's learning: A case study of using iPads in American preschools. International Journal of Information and Education Technology, 5(12), 947-950. https://doi.org/10.7763/ijiet.2015.v5.643

Loukotková, E. (2011). Young learners and teenagers - Analysis of their attitudes to English language learning.

Nurkancana, W., \& Sunartana, P. (1992). Evaluasi hasil belajar. Surabaya: Usaha Nasional.

Pais, M. H. R., Nogués, F. P., \& Muñoz, B. R. (2017). Incorporating Powtoon as a learning activity into a course on technological innovations as didactic resources for pedagogy programs. International Journal of Emerging Technologies in Learning (IJET), 12(6), 120131. https://doi.org/10.3991/ijet.v12i06.7025 
Puspitarini, Y. D., Akhyar, M., \& Djono, D. (2016). Developing Powtoon-based video learning media for five grade students of elementary school. In 2nd International Conference of Communication Science Research (ICCSR 2018) (Vol. 165, pp. 173-177). https://doi.org/10.2991/iccsr-18.2018.37

Richey, R. C., \& Klein, J. D. (2016). Design and development research (1st edition). Routledge. Romiszowski, A. J. (1984). Designing instructional systems. Nichols Pub Co.

Seemiller, C., \& Grace, M. (2017). Move over millennials, generation $Z$ is here! Leadership Programs. Retrieved from http://www.forbes.com/sites/lauraheller/2015/08/14/move-overmillennials-generation-z-is-in-charge/

Semaan, C., \& Ismail, N. (2018). The effect of using Powtoon on learning English as a foreign language. International Journal of Current Research, 10(5), 69262-69265.

Suprianti, G. A. P., Mahayanti, N. W. S., \& Kusuma, I. P. I. (2018). The use of flashcards as teaching media at elementary schools: Students' and teachers' perception. In 4th International Conference on English across Culture (pp. 378-391). Bali: Undiksha Press. https://doi.org/10.1029/jb095ib09p14089

Suprianti, G. A. P., Mahayanti, N. W. S., \& Suarjaya, P. A. A. . (2020). Learning English in Third Grade through Powtoon. Journal of Education Technology, 4(2), 120. https://doi.org/10.23887/jet.v4i2.24087

Turgut, Y., \& Irgin, P. (2009). Young learners' language learning via computer games. Procedia - Social and Behavioral Sciences, 1, 760-764. https://doi.org/10.1016/j.sbspro.2009.01.135

Porvaldsdóttir, G. H. (2008). Songs as teaching resources in the young learners ' ESL classroom. 